Annals of Warsaw University of Life Sciences - SGGW

Land Reclamation No 45 (2), 2013: 243-253

(Ann. Warsaw Univ. of Life Sci. - SGGW, Land Reclam. 45 (2), 2013)

\title{
Effects of road traffic on the ambient concentrations of three PM fractions and their main components in a large Upper Silesian city
}

\author{
WIOLETTA ROGULA-KOZLOWSKA, PATRYCJA ROGULA-KUPIEC, \\ BARBARA MATHEWS, KRZYSZTOF KLEJNOWSKI \\ Institute of Environmental Engineering of the Polish Academy of Sciences
}

\begin{abstract}
Effects of road traffic on the ambient concentrations of three PM fractions and their main components in a large Upper Silesian city. The study concerns the assessment of the traffic influence on the concentrations of three particulate matter (PM) fractions and their basic components. The PM samples were collected simultaneously at two receptors in Katowice. The measurement sites represented the so-called urban background and traffic points. The contents of the organic and elementary carbon as well as water-soluble ions were determined in the samples. It has been observed that the traffic (car engines) pollution emissions enrich the submicron and fine PM particles with the elementary carbon at a typical urban background in southern Poland. On the other hand, the influence of the re-suspension of the road and soil dust, caused by traffic, on the concentrations and chemical composition is observed for the coarse PM fraction.
\end{abstract}

Key words: $\mathrm{PM}_{1}, \mathrm{PM}_{1-2.5}, \mathrm{PM}_{2.5-10}$, elemental carbon, organic carbon, chemical composition, size distribution, traffic site, urban background

\section{INTRODUCTION}

Road traffic has a significant influence on the environment. It also influences pollutant concentrations in the air (e.g. Versulis 1994, Morawska et al. 1999). Dusts emitted from streets, crossroads or motorways are mainly made of particles emitted from cars. They also contain settled dust re-emitted from road and kerb surfaces due to the traffic. The car engine emissions tend to decrease owing to the legal restrictions and devices designed to clean flue gases (diesel particulate filters, DPFs). For example, the research conducted in the Caldecott Tunnel (USA) showed that the coefficient values for the emission of particles with diameters of up to $2.5 \mu \mathrm{m}\left(\mathrm{PM}_{2.5}\right)$ declined. The study (Ban-Weiss et al. 2008) indicates that the values changed from $0.11 \pm 0.01$ ( $\mathrm{g}$ of $\mathrm{PM}_{2.5}$ per $\mathrm{kg}$ of fuel) in 1997 to $0.07 \pm 0.02$ in 2006 for gasoline engines. For the diesel ones, the values dropped from $2.7 \pm 0.3$ (g of $\mathrm{PM}_{2.5}$ per $\mathrm{kg}$ of fuel) in 1997 to $1.4 \pm 0.3$ in 2006 .

The most detailed information on the characteristics of the dust emitted from cars can be obtained from the research conducted in road tunnels. Such measurements were performed by Pierson and Brachaczek in the mountain tunnels in Allegheny and Tuscarora (USA) between 1970 and 1979. The researchers applied a complex set of apparatus and methodologies. Their investigations helped to identify the dust. Its main sources were exhaust pipes, tyre and brake lining abrasion and the soil particle re-emission. Only $3.5 \%$ of the dust had an unknown origin. Approximately $80 \%$ of the particulate matter (PM) mass was constituted by carbon compounds, 
mainly from heavy diesels $(10-15 \%$ of the whole traffic); sulphates made up $5 \%$; inorganic matter from fuel and oil made up $10 \%$; tyres and soil particles constituted $1 \%$ and $10 \%$, respectively.

The studies conducted in road tunnels by Weingartner et al. (1997) in 1993, Kirchstetter et al. (1999) in 1997, Allen et al. (2001) in 1999 and Geller et al. (2005) in 2004 demonstrated that carbon (both elemental and organic) had the biggest percentage in the researched PM masses.

Recently, the research on the influence that the traffic emission exerts on the atmospheric air quality has been focused on the search for and evaluation of the PM concentrations and chemical compositions. The examinations have been carried out at tunnels, street canyons, and surroundings of busy roads but also at sites that are not under the influence of traffic.

The studies show that traffic is an important source of the $\mathrm{PM}_{2.5}$ fraction (Väkevä et al. 1999, Zhu et al. 2002, Slezakowa et al. 2007). At some places, it also contributes to the emission of the coarse fraction $-\mathrm{PM}_{2.5-10}$, particles with diameters of $2.5-10 \mu \mathrm{m}$ (Hueglin et al. 2005).

The investigation undertaken in Switzerland demonstrates that the $\mathrm{PM}_{10}$ (particles with diameters of up to $10 \mu \mathrm{m}$ ) increase at kerbsites reached $64 \%$ when compared with the urban background. However, the increase in $\mathrm{PM}_{2.5}$ was only $23 \%$ (Hueglin et al. 2005). On the other hand, some studies estimate that the traffic emission constitutes at least $50 \%$ of the $\mathrm{PM}_{2.5}$ mass (Harrison et al. 2004).

Hueglin et al. (2005) conducted one of the first complex studies in Europe that concerned the changes in the chemical composition of the aerosol under the traffic emission influence. They found out that sulphate and nitrate percentages in the yearly concentrations of $\mathrm{PM}_{2.5}$ and $\mathrm{PM}_{10}$ were higher in the rural, suburban and urban background areas than at the sites under the traffic influence (Hueglin et al. 2005). At the sites where the traffic influence was heavy, the organic matter (OM) and elemental carbon (EC) had the biggest percentages in the yearly concentrations of $\mathrm{PM}_{2.5}$ and $\mathrm{PM}_{10}$. EC constituted around $14-18 \%$ of the PM mass concentrations. Its percentage was $5-10 \%$ at the sites that were not under the traffic emission influence (Hueglin et al. 2005).

The traffic emission influence on the physicochemical structure of the aerosol was also observed in the Upper Silesian urban area (Rogula-Kozłowska et al. 2008, 2011). It was discovered in the close vicinity of roads and crossroads. Nonetheless, the research conducted so far has concentrated on short-term measurements of the $\mathrm{PM}_{2.5}$ or $\mathrm{PM}_{10}$ concentrations. It has also concerned analyses of the element compositions, but mainly in the surface layer of the collected PM samples. It has been concluded that, contrary to other regions, the PM concentrations in the Upper Silesian urban area are still formed by the municipal and industrial sources. The traffic emission is less important.

The following study evaluates the traffic influence on the concentrations and chemical compositions of three PM fractions collected at the same time, i.e. $\mathrm{PM}_{1}, \mathrm{PM}_{1-2.5}, \mathrm{PM}_{2.5-10}$ (particle diameters of up to $1,1-2.5$ and $2.5-10 \mu \mathrm{m}$, respectively). The presented paper is 
a part of the first complex evaluation of the traffic influence on the physicochemical properties of $\mathrm{PM}$, including the submicron fraction $\left(\mathrm{PM}_{1}\right)$, carried out in Poland.

\section{MATERIAL AND METHODS}

The PM samples were collected at two sampling points in Katowice. One of the points was located in the area meeting the requirements of the Directive 2008/50/ /EC for locations representing the so-called urban background. According to the Directive, such a point must represent inhabitants' exposition to the ambient concentration in the residential areas of larger urban agglomerations, in which the air quality is mainly influenced by the municipal and industrial emissions. The site chosen for the research was located in the vicinity of a large residential area in the Muchowiec district. It was marked with the TM symbol. The other point, i.e. the so-called traffic point (marked with the A4 symbol) was located in the area directly influenced by the traffic emission. It was placed at the A4 motorway kerb, approximately $1.5 \mathrm{~km}$ south of the city centre.

The samples were collected in the spring-summer season (mid-March to mid-June 2012). The winter season was excluded from the investigation due to the increased municipal emission of the PM (particularly carbon compounds) that could conceal the traffic emission influence (Rogula-Kozłowska et al. 2008, 2013). Each measurement lasted around 1 week. The longest one took $173 \mathrm{~h}$, while the shortest one lasted $142 \mathrm{~h}$. Altogether, 9 measurements were performed.
Two thirteen-stage low-pressure impactors (DLPI, Dekati Low Pressure Impactor) were used for the sampling. DLPIs are used to determine the mass distribution of the collected material (PM and/or its components; in this case - carbon and ions present in the PM samples) in relation to the particle size, for the particle diameter range of $0.03-10 \mu \mathrm{m}$ and at the flow rate of $30 \mathrm{l} / \mathrm{min}$ (Klejnowski et al. 2010).

The PM samples were collected on special substrates (nylon membranes or quartz filters). Their masses were determined through weighing the substrates on the Rawag microbalance (1- $\mu \mathrm{g}$ resolution) before and after the exposition. Before and after the exposition, the filters were conditioned in a weighing room $(48 \mathrm{~h}$, relative air humidity 45 $\pm 5 \%$, air temperature $20 \pm 2^{\circ} \mathrm{C}$ ). All the operations related to the impactor preparation for the examinations, including the filter mounting onto the impactor stages, were carried out in the sterile air stream inside a laminar flow cabinet. After sampling in the field, the filters with the PM were transferred into sterile glass Petrie dishes in the laminar flow cabinet. Immediately after the filters with the PM were weighed, they were put into a refrigerator. They were kept there until the analysis took place.

At both sampling points, the samples were collected alternately (every second measurement) onto the quartz filters (Whatman, QMA, ø $2.5 \mathrm{~mm}$, CAT No. 1851-025) or nylon membranes (Whatman, Nylon Membrane Filters $0.2 \mu \mathrm{m}$, $\varnothing 25 \mathrm{~mm}$, Cat No. 7402-002). The samples deposited on the quartz filters were analysed for the organic carbon (OC) and EC contents. The samples collected 
on the nylon membranes were extracted in water. The water extracts were used to determine the concentrations of the main ions $\mathrm{Cl}^{-}, \mathrm{NO}_{3}^{-}, \mathrm{SO}_{4}{ }^{2-}, \mathrm{Na}^{+}, \mathrm{NH}_{4}^{+}, \mathrm{K}^{+}$, $\left.\mathrm{Ca}^{2+}, \mathrm{Mg}^{2+}\right)$. The analytical procedures and apparatus applied to the chemical analysis of the samples were discussed in detail in the paper (Rogula-Kozłowska and Klejnowski 2013).
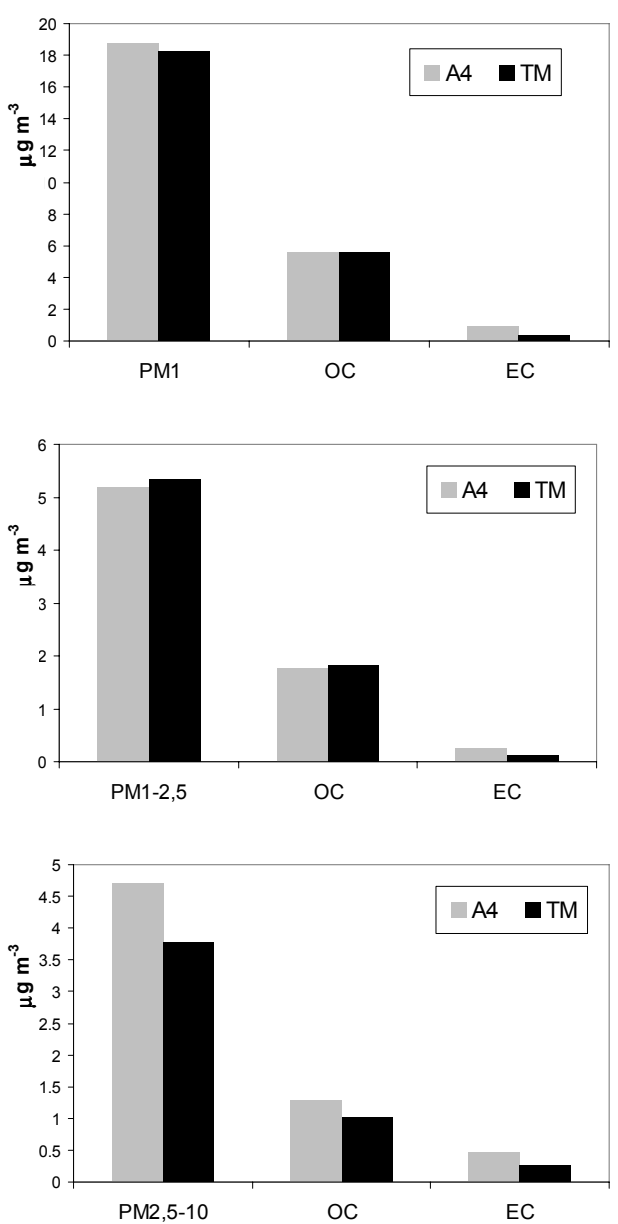

\section{RESULTS}

The $\mathrm{PM}_{1}, \mathrm{PM}_{1-2.5}$ and $\mathrm{PM}_{2.5-10}$ concentration values were similar at the A4 and TM sampling points (Fig. 1, Table 1). The visible increase (approx. 25\%) in the concentration at the A4 point in relation to the TM one was observed only for the coarse PM fraction $\left(\mathrm{PM}_{2.5-10}\right)$. For the submicron PM $\left(\mathrm{PM}_{1}\right)$, only the 3-percentage increase was observed at motorway,
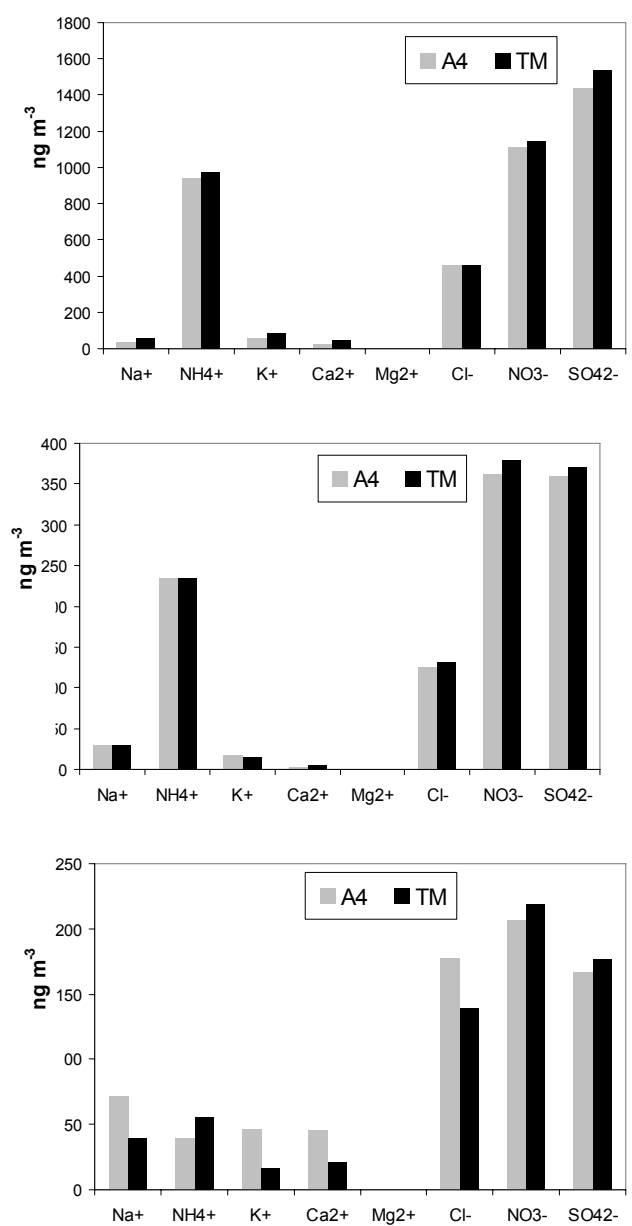

FIGURE 1. Concentrations of $\mathrm{PM}_{1}, \mathrm{PM}_{1-2.5}, \mathrm{PM}_{2.5-10}$ and $\mathrm{OC} / \mathrm{EC}$ bound to these fractions (on the left) and concentrations of water-soluble ions (on the right) bound to $\mathrm{PM}_{1}, \mathrm{PM}_{1-2.5}, \mathrm{PM}_{2.5-10}$ at the $\mathrm{A} 4$ and TM sampling points in Katowice 
TABLE 1. The ratio of the PM concentration and its main components in three PM fractions at the A4 and TM sampling points

\begin{tabular}{lccccccccccc}
\hline Fraction & $\mathrm{PM}$ & $\mathrm{OC}$ & $\mathrm{EC}$ & $\mathrm{Na}^{+}$ & $\mathrm{NH}_{4}^{+}$ & $\mathrm{K}^{+}$ & $\mathrm{Ca}^{2+}$ & $\mathrm{Mg}^{2+}$ & $\mathrm{Cl}^{-}$ & $\mathrm{NO}_{3}^{-}$ & $\mathrm{SO}_{4}^{2-}$ \\
\hline $\mathrm{PM}_{1}$ & $\mathbf{1 . 0 3}$ & 1.00 & $\mathbf{2 . 8 0}$ & 0.73 & 0.97 & 0.68 & 0.53 & - & $\mathbf{1 . 0 1}$ & 0.97 & 0.93 \\
$\mathrm{PM}_{1-2.5}$ & 0.97 & 0.97 & $\mathbf{1 . 8 2}$ & $\mathbf{1 . 0 1}$ & 1.00 & $\mathbf{1 . 2 4}$ & 0.50 & - & 0.96 & 0.95 & 0.97 \\
$\mathrm{PM}_{2.5-10}$ & $\mathbf{1 . 2 5}$ & $\mathbf{1 . 2 7}$ & $\mathbf{1 . 7 6}$ & $\mathbf{1 . 8 4}$ & 0.71 & $\mathbf{2 . 8 0}$ & $\mathbf{2 . 2 0}$ & - & $\mathbf{1 . 2 8}$ & 0.94 & 0.95 \\
\hline
\end{tabular}

when compared to the average value observed in the urban background. Nevertheless, the $\mathrm{PM}_{1}$ concentrations at both sampling points were high even though the measurements were carried out in the warm season, when the PM concentrations in Poland are generally lower than in the cold season (because of emission and metrological/bioclimatic conditions, e.g. Pastuszka et al. 2003, Klejnowski et al. 2007, 2010, Juda-Rezler et al. 2011, Majewski et al. 2011, Zwoździak et al. 2012, Majewski and Ćwiek 2013, Rogula-Kozłowska and Klejnowski 2013). The sum of the average $\mathrm{PM}_{1}$ and $\mathrm{PM}_{1-2.5}$ (fine dust) concentrations was close to the average permissible yearly value for $\mathrm{PM}_{2.5}\left(25 \mu \mathrm{g} / \mathrm{m}^{3}\right)$.

As it has been shown in the Introduction, the dust in the engine flue gases contains EC particles, PAHs from incomplete fuel combustion, compounds formed from the re-synthesis of fuel residues, and substances used as additives to fuels and oils. The traffic emission influence at the motorway demonstrated itself through the visibly higher (for the A4 point) EC concentrations. They were nearly three times higher at the A4 than the TM point. The EC concentrations were nearly twice as high for the $\mathrm{PM}_{1-2.5}$ and $\mathrm{PM}_{2.5-10}$ fractions at the $\mathrm{A} 4$ point (Table 1).

Contrary to other European locations, $\mathrm{EC}$ was not mainly concentrated in the submicron and fine PM (Fig. 1); at both points in Katowice (Rogula-Kozłowska et al. 2013). It also concerned the location that was directly exposed to the traffic emission. It seems possible that the significant contribution of the municipal emission to the EC balance in Katowice was responsible for the fact that coarse particles $\left(\mathrm{PM}_{2.5-10}\right)$ were enriched with EC. Low-performance, obsolete coal furnaces are used by Upper Silesian inhabitants to cook and heat water throughout the year. Consequently, they make emitters of large soot agglomerates from incomplete combustion. The unusual increase in the $\mathrm{PM}_{2.5-10}$-related EC concentrations at the traffic point (in comparison with the corresponding concentrations at the urban background point) may be related to the fact that old cars with faulty DPFs move along the roads. As a result, large particles (soot agglomerates) can be emitted.

In areas where traffic influences the concentrations of the PM and its components, the road proximity causes a decrease in the OC/EC ratio when compared to the values observed at sites far afield from the roads (Rogula-Kozłowska et al. 2013). The high OC/EC concentration ratio for the submicron and fine PM (Fig. 1) can indicate that the A4 motorway traffic volume and the fine EC particle emission related to it are not high enough to change the ratio value as it happens at 
other similar locations. In Upper Silesian cities and towns, the lower OC/EC ratio is observed during the heating season, irrespective of the sampling point location (Rogula-Kozłowska et al. in press).

For the coarse fraction $\left(\mathrm{PM}_{2.5-10}\right)$, the OC concentration was higher by $27 \%$ at the A4 point than at the TM one. It is probably related to the adsorption of organic compounds on the coarse - either mineral or soot - PM particles (Seinfeld and Pandis 2006). The OC concentrations were similar for the remaining fractions at both points (Fig. 1, Table 1).

The so-called secondary atmospheric aerosol $\left(\mathrm{NH}_{4}^{+}, \mathrm{NO}_{3}^{-}, \mathrm{SO}_{4}{ }^{2-}\right)$ forms because of the photochemical transformations of the particle gas precursors (Seinfeld and Pandis 2006). The concentrations of its components were similar at both points (A4 and TM). For the $\mathrm{PM}_{2.5-10}$ fraction, the equivalent ion balance (Table 2) shows that the secondary inorganic aerosol (SIA) probably contained only ammonium sulphate $\left(\left(\mathrm{NH}_{4}\right)_{2} \mathrm{SO}_{4}\right)$ at both sampling points. The SIA contained both ammonium sulphate and ammonium nitrate $\left(\mathrm{NH}_{4} \mathrm{NO}_{3}\right)$ in $\mathrm{PM}_{1}$ and $\mathrm{PM}_{1-2.5}$.

The conclusions are drawn on the basis of the commonly used but highly simplified balancing of PM-related cations and anions. Some studies reveal that the atmospheric aerosol can have acidic $\mathrm{pH}$ (due to the sulphuric acid presence) even if the ratio of $\mathrm{NH}_{4}^{+} / \mathrm{SO}_{4}{ }^{2-}$ mass equivalent is higher than 2 or even (i.e. $\mathrm{SO}_{4}{ }^{2-} /$ $/ \mathrm{NH}_{4}{ }^{+} \leq 0.5$ (Pathak et al. 2009, Huang et al. 2011).

Low values of the ratio of total cation equivalent to total anion equivalent $\left(\Sigma_{\text {cations }} / \Sigma_{\text {anions }}\right.$, Table 2$)$ at both sampling points follow the findings on the possibly acidic $\mathrm{pH}$ of the aerosol in Katowice. Consequently, the $\left(\mathrm{NH}_{4}\right)_{2} \mathrm{SO}_{4}$ concentrations estimated with simple stoichiometric computations can be slightly inflated as the computations assume that sulphates should react completely with ammonium ions at $\mathrm{NH}_{4}{ }^{+} / \mathrm{SO}_{4}{ }^{2-} \geq 1$.

Low values of the ratio of total cation equivalent to total anion equivalent $\left(\Sigma_{\text {cations }} / \Sigma_{\text {anions }}\right)$ at both sampling points (much lower than 1 for $\mathrm{PM}_{2.5-10}$ ) do not

TABLE 2. Equivalent ion balance and probable composition of the SIA composition in $\mathrm{PM}_{1}, \mathrm{PM}_{1-2.5}$, $\mathrm{PM}_{2.5-10}$ at the $\mathrm{A} 4$ and $\mathrm{TM}$ points

\begin{tabular}{|c|c|c|c|c|c|c|}
\hline \multirow{2}{*}{ Specification } & $\mathrm{PM}_{1}$ & $\mathrm{PM}_{1-2.5}$ & $\mathrm{PM}_{2.5-10}$ & $\mathrm{PM}_{1}$ & $\mathrm{PM}_{1-2.5}$ & $\mathrm{PM}_{2.5-10}$ \\
\hline & \multicolumn{3}{|c|}{ A4 } & \multicolumn{3}{|c|}{$\mathrm{TM}$} \\
\hline$\Sigma_{\text {cations }} / \Sigma_{\text {anions }}\left[\mathrm{neqm}^{-3} / \mathrm{neqm}^{-3}\right]$ & 0.92 & 0.87 & 0.73 & 0.95 & 0.84 & 0.55 \\
\hline $\mathrm{NR}^{\mathrm{a}}\left[\mathrm{neqm}^{-3} /\right.$ neqm $\left.^{-3}\right]$ & 1.08 & 0.96 & 0.32 & 1.06 & 0.93 & 0.42 \\
\hline $\mathrm{SO}_{4}{ }^{2-} / \mathrm{NH}_{4}{ }^{+}\left[\right.$neqm $^{-3} /$ neqm $\left.^{-3}\right]$ & 0.57 & 0.58 & 1.59 & 0.59 & 0.59 & 1.20 \\
\hline$\left[\left(\mathrm{NH}_{4}\right)_{2} \mathrm{SO}_{4}\right]^{\mathrm{b}}\left[\mu \mathrm{gm}^{-3}\right]$ & 1.98 & 0.50 & 0.14 & 2.12 & 0.51 & 0.20 \\
\hline$\left[\mathrm{ex}-\mathrm{NH}_{4}{ }^{+}\right]^{\mathrm{c}}\left[\mu \mathrm{gm}^{-3}\right]$ & 0.40 & 0.10 & 0.00 & 0.40 & 0.10 & 0.00 \\
\hline$\left[\mathrm{NH}_{4} \mathrm{NO}_{3}\right]^{\mathrm{d}}\left[\mu \mathrm{gm}^{-3}\right]$ & 1.79 & 0.45 & 0.00 & 1.77 & 0.43 & 0.00 \\
\hline
\end{tabular}

$\mathrm{a}-\mathrm{NR}=\mathrm{NH}_{4}{ }^{+} /\left(\mathrm{SO}_{4}{ }^{2-}+\mathrm{NO}_{3}^{-}\right)$.

$\mathrm{b}^{-}\left[\left(\mathrm{NH}_{4}\right)_{2} \mathrm{SO}_{4}\right]=1.38\left[\mathrm{SO}_{4}{ }^{2-}\right]$ if $\mathrm{SO}_{4}{ }^{2-} / \mathrm{NH}_{4}{ }^{+}<1$ and $\left[\left(\mathrm{NH}_{4}\right)_{2} \mathrm{SO}_{4}\right]=3.67\left[\mathrm{NH}_{4}^{+}\right]$if $\mathrm{SO}_{4}{ }^{2-} / \mathrm{NH}_{4}{ }^{+}>1$.

$\mathrm{c}-\left[\mathrm{ex}-\mathrm{NH}_{4}^{+}\right]=\left[\mathrm{NH}_{4}^{+}\right]-0.27\left[\left(\mathrm{NH}_{4}\right)_{2} \mathrm{SO}_{4}\right]$.

$\mathrm{d}-\left[\mathrm{NH}_{4} \mathrm{NO}_{3}\right]=4.44\left[\mathrm{ex}-\mathrm{NH}_{4}^{+}\right]$. 
prove that some anions in PM were not neutralized. They show that the determined main dust components constituted only a part of the total PM mass. It is probable that the insoluble fractions of $\mathrm{Ca}, \mathrm{Mg}$ or $\mathrm{K}$ (not analysed in this study) as well as other elements, mainly $\mathrm{H}$ (component of nitric and sulphuric acids) balanced the anions occurring in the aerosol.

The particles with a diverse fraction composition, with the predominant mass percentage of coarse particles (Pierson and Brachaczek 1983, Allen et al. 2001), are emitted as a result of the mechanical wear of the materials used to produce cars and harden road surfaces. The road surfaces also make a significant source of the secondary emission (usually coarse particles), particularly in the periods without precipitation and in winter, when chemical substances are used to prevent the black ice (e.g. Pastuszka et al. 2010). Importantly, these findings explain the visibly higher $\mathrm{K}, \mathrm{Ca}, \mathrm{Na}$ and $\mathrm{Cl}$ concentrations in the coarse PM, which occurred at the A4 point (Fig. 1, Table 1).
The sum of the identified PM components constituted between nearly $58 \%\left(\mathrm{PM}_{2.5-10}\right)$ and approximately $73 \%$ $\left(\mathrm{PM}_{1-2.5}\right)$ of the PM mass at the A4 sampling point. In the urban background (TM), the determined PM components helped to reconstruct between 56\% $\left(\mathrm{PM}_{2.5-10}\right)$ and $71 \%\left(\mathrm{PM}_{1-2.5}\right)$ of the PM mass (Fig. 2). The coarse PM at the urban background point contained considerably more primary matter. It mainly concerned primary organic matter (OMprim). The same PM fraction collected at the motorway contained significantly more secondary organic matter (OMsec), i.e. matter formed as a consequence of the transformation reaction of the gas precursors into particles (Castro 1999, Seinfeld and Pandis 2006). On the other hand, there was more OMsec in the fine and submicron PM at the urban background (TM).

In general, the PM mass at the motorway contained between $30\left(\mathrm{PM}_{2.5-10}\right)$ and $60 \%\left(\mathrm{PM}_{1-2.5}\right)$ of the secondary compounds - OMsec, $\mathrm{NH}_{4} \mathrm{NO}_{3}$ and $\left.\left(\mathrm{NH}_{4}\right)_{2} \mathrm{SO}_{4}\right)$. The remaining part of the
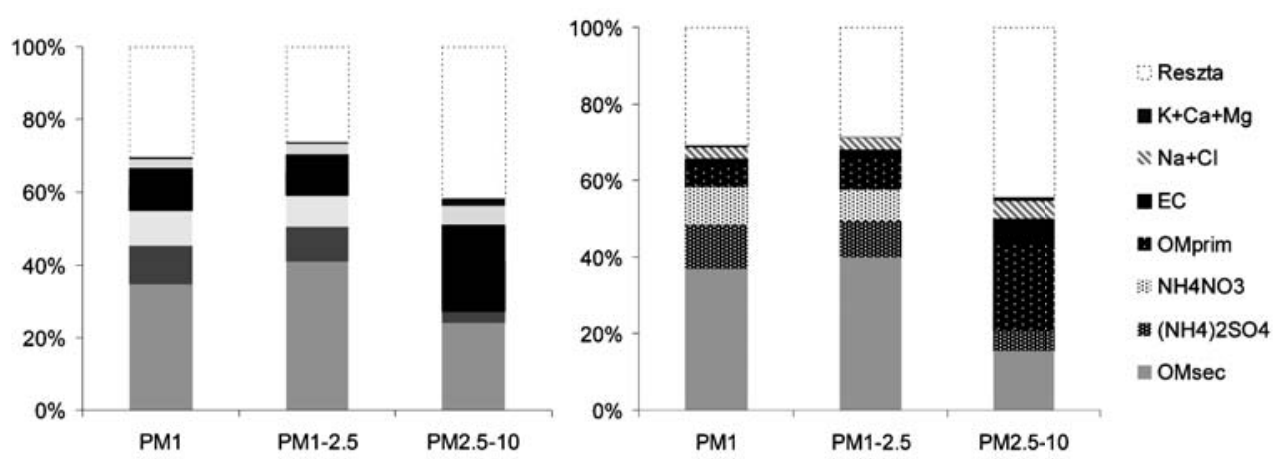

$\mathrm{OM}-$ organic matter $(\mathrm{OM}=1.4 \times \mathrm{OC})$; the division of $\mathrm{OM}$ into $\mathrm{OMsec}$ and OMprim was based on the scheme discussed in the study (Rogula-Kozłowska et al. 2013); the $\mathrm{NH}_{4} \mathrm{NO}_{3}$ and $\left(\mathrm{NH}_{4}\right)_{2} \mathrm{SO}_{4}$ concentrations were assumed in accordance with the results given in Table 2.

FIGURE 2. Mass reconstruction of three PM fractions at the traffic sampling point at the motorway (A4, on the left) and at the urban background point (TM, on the right) in Katowice 
identified PM mass was composed of primary compounds (OMprim, $\mathrm{EC}, \mathrm{Na}+$ $+\mathrm{Cl}$ and $\mathrm{K}+\mathrm{Ca}+\mathrm{Mg})$. At the urban background point, the secondary aerosol - both organic (OMsec) and inorganic one $\left(\mathrm{NH}_{4} \mathrm{NO}_{3}\right.$ and $\left.\left(\mathrm{NH}_{4}\right)_{2} \mathrm{SO}_{4}\right)$ - made up between $20\left(\mathrm{PM}_{2.5-10}\right)$ and $60 \%\left(\mathrm{PM}_{1}\right.$ and $\mathrm{PM}_{1-2.5}$ ) of the PM mass (Fig. 2).

The discrepancies between the PM mass and the sum of its components arise from the fact that a group of compounds that were not chemically analysed occurred in the dust (a number of elements, carbonaceous and/or organic anions). The lack of the so-called complete mass closure (mass reconstruction) can be also related to the evaporation of the organic compounds and nitrates during the transport and storage of the PM samples (particularly in warm and dry periods). The presence of water bound to the PM particles is a very important factor that exerts impact on the chemical balance of the PM mass. The study (Tsyro 2005) demonstrates that the water percentage under the 50-percentage $\mathrm{RH}$ conditions varies in different European areas. It can constitute $20-35 \%$ of the $\mathrm{PM}_{2.5}$ mass. Additionally, the results of the chemical reconstruction of the PM mass are also influenced by the errors and measurement uncertainty related to each research stage (sampling, gravimetric and chemical analyses).

\section{CONCLUSIONS}

The PM concentrations and components were determined for three selected PM fractions (submicron, fine and coarse) at two sampling points, i.e. the A4, located at the motorway, and the TM, placed in the so-called urban background. The analysis did not indicate any particular differences between the parameters investigated at both points.

The differences in the PM concentrations were visible only for the coarse PM fraction as they were higher by $25 \%$ at the A4 point than at the TM one. The differences in the PM chemical composition were slight at both points. There was definitely more EC in the city centre at the motorway. At this spot, the coarse PM fraction contained more OMsec, whereas its content in the submicron PM fraction was undeniably lower than at the urban background point. On the other hand, there were more primary components related to the resuspension and other mechanical processes (i.e. wear/ /erosion of the materials used to produce cars and harden the road surfaces) in the coarse PM mass at the motorway.

The analysis of the obtained results confirms that the traffic emission can have a less significant influence on the concentrations and chemical composition of the three analysed PM fractions in Katowice than in other European regions.

\section{Acknowledgments}

The work was realized within the projects C.1.2. and N N523 564038, the former financed by the Institute of Environmental Engineering, PAS, the latter-by the Polish Ministry of Science and Higher Education. 


\section{REFERENCES}

ALLEN J.O., MAYO P.R., HUGHES L.S., SALMON L.G, CASS G.R. 2001: Emission of size-segregated aerosols from on-road vehicles in the Caldecott Tunnel. Environmental Science and Technology 35: 4189-4197.

BAN-WEISS G.A., McLAUGHLIN J.P., HARLEY R.A., LUNDEN M.M., KIRCHSTETTER T.W., KEAN A.J., STRAWA A.W., STEVENSON E.D., KENDALL G.R. 2008: Long-term changes in emission of nitrogen oxides and particulate matter from on-road gasoline and diesel vehicles. Atmospheric Environment 42: 220-232.

CASTRO L.M., PIO C.A., HARRISON R.M., SMITH D.J.T. 1999: Carbonaceous aerosol in urban and rural European atmospheres: estimation of secondary organic carbon concentrations. Atmospheric Environment 33: 2771-2781.

GELLER M.D., SARDAR S.B., PHULERIA H., FINE P.M., SIOUTAS C. 2005: Measurements of particle number and mass concentrations and size distributions in tunnel environment. Environmental Science and Technology 39: 8653-8663.

HARRISON R.M., JONES A.M., LAWRENCE R.G. 2004: Major component composition of PM10 and PM2,5 from roadside and urban background sites. Atmospheric Environment 38, 4531-4538.

HUANG X., QIU R., CHAK K.Ch, PATHAK R.K. 2011: Evidence of high PM2.5 strong acidity in ammonia-rich atmosphere of Guangzhou, China: Transition in pathways of ambient ammonia to form aerosol ammonium at $\left[\mathrm{NH}_{4}{ }^{+}\right] /$ $/\left[\mathrm{SO}_{4}{ }^{2-}\right]=1.5$. Atmospheric Research, 99 , 488-495.

HUEGLIN C., GEHRIG R., BALTENSPERGER U., GYSEL M., MONN C., VONMONT H. 2005: Chemical characterization of PM2,5, PM10 and coarse particles at urban, near-city and rural sites in Switzerland. Atmospheric Environment 39, 637-651.

JUDA-REZLER K., REIZER M., OUDINET J.-P. 2011: Determination and analysis of $\mathrm{PM}_{10}$ source apportionment during episodes of air pollution in Central Eastern European urban areas: The case of wintertime 2006. Atmospheric Environment 45: 6557-6566.

KIRCHSTETTER T.W., HARLEY R.A., KREISBERG N.M., STOLZENBURG M.R., HERRING S.V. 1999: Onroad measurement of fine particles and nitrogen oxide emission from light- and heavy-duty motor vehicles. Atmospheric Environment 33: 2955-2968.

KLEJNOWSKI K., KRASA A., ROGULA W. 2007: Seasonal variability of concentrations of total suspended particles (TSP) as well as PM10, PM2.5 and PM1 modes in Zabrze, Poland. Archives of Environmental Protection 33(3): 15-29.

KLEJNOWSKI K., KRASA A., ROGULA-KOZŁOWSKA W. 2010: Mass size distribution of total suspended particulates in Zabrze (Poland). [In] Environmental Engineering III, Pawłowski, Dudzińska \& Pawłowski (Eds.). Taylor \& Francis Group, London: 37-43, 125.

MAJEWSKI G., ĆWIEK K. 2013: Effect of a different degree of anthropogenic transformation on the formation of bioclimatic conditions - Warsaw case study. Annals of Warsaw University of Life Sciences SGGW. Land Reclamation 45 (1): 97-109.

MAJEWSKI G., KLENIEWSKA M., BRANDYK A. 2011: Seasonal Variation of Particulate Matter Mass Concentration and Content of Metals. Polish Journal of Environmental Studies, 20(2): 417-427.

MORAWSKA L., THOMAS S., GILBERT D., GREENAWAY CH., RIJNDERS E. 1999: A study of the horizontal and vertical profile of submicrometer particles in relation to a busy road. Atmospheric Environment 33: 1261-1274. 
PASTUSZKA J.S., ROGULA-KOZŁOWSKA W., ZAJUSZ-ZUBEK E. 2010: Characterization of PM10 and PM2.5 and associated heavy metals at the crossroads and urban background site in Zabrze, Upper Silesia, Poland, during the smog episodes. Environmental Monitoring and Assessment 168: 613-627.

PASTUSZKA J.S., WAWROŚ A., TALIK E., PAW U.K.T. 2003: Optical and chemical characteristics of the atmospheric aerosol in four towns in southern Poland. The Science of the Total Environment 309: 237-251.

PATHAK R.K., WU W.S., WANG T. 2009: Summertime PM2.5 ionic species in four major cities of China: nitrate formation in an ammonia-deficient atmosphere. Atmospheric Chemistry and Physics 9: 1711-1722.

PIERSON W.R., BRACHACZEK W.W. 1983: Particulate matter associated with vehicles on the road. II. Aerosol Science and Technology 2: 1-40.

ROGULA-KOZŁOWSKA W., KLEJNOWSKI K. 2013: Submicrometer Aerosol in Rural and Urban Backgrounds in Southern Poland: Primary and Secondary Components of PM1. Bulletin of Environmental Contamination and Toxicology 90 (1): 103-109.

ROGULA-KOZŁOWSKA W., KLEJNOWSKI K., ROGULA-KOPIEC P., OŚRÓDKA L., KRAJNY E., BŁASZCZAK B., MATHEWS B. (in press). Spatial and seasonal variability of the mass concentration and chemical composition of PM2.5 in Poland. Air Quality, Atmosphere $\&$ Health. (http://dx.doi.org/10.1007/ s11869-013-0222-y).

ROGULA-KOZŁOWSKA W., PASTUSZKA J.S., TALIK E. 2008: Influence of vehicular traffic on concentration and particle surface composition of PM10 and PM2,5 in Zabrze, Poland. Polish Journal of Environmental Studies 4: 539-548.
ROGULA-KOZŁOWSKA W., PASTUSZKA J.S., TALIK E. 2011: Właściwości aerozolu ze źródeł komunikacyjnych. and Prace i Studia, IPIŚ PAN, Zabrze 80: $1-111$.

ROGULA-KOZŁOWSKA W., ROGULA-KOPIEC P., KLEJNOWSKI K., BŁASZCZYK J. 2013: Wpływ emisji komunikacyjnej na stężenie dwóch form węgla i rozkład ich masy względem wielkości cząstek w aerozolu atmosferycznym obszaru miejskiego. Rocznik Ochrony Środowiska 15: 1623-1644.

SEINFELD J.H., PANDIS S.N. 2006: Atmospheric Chemistry and Physics: From Air Pollution to Climate Change. John Wiley \& Sons, London.

SLEZAKOWA K., PEREIRA M.C., REIS M.A., ALVIM-FERRAZ M.C. 2007: Influence of traffic on the composition of atmospheric particles of different sizes - Part 1: Concentrations and elemental characterization. Journal of Atmospheric Chemistry 58: 55-68.

TSYRO S.G. 2005: To what extent can aerosol water explain the discrepancy between model calculated and gravimetric PM10 and PM2.5. Atmospheric Chemistry and Physics 5: 515-32.

VÄKEVÄ M., HÄMERI K., LAHDES R., RUUSKANEN J., LAITINEN T. 1999: Streeet level versus rooftop concentrations of submicron aerosol particles and gaseous pollutants in an urban street canyon. Atmospheric Environment 33: 1385-1397.

VERSULIS A.H. 1994: Methodology for predicting vehicle emissions on motorways and their impact on air quality in the Netherlands. The Science of the Total Environment 146/147: 359-364.

WEINGARTNER E., KELLER C., STAHEL W.A., BURTSCHER H., BATENSPELGER U. 1997: Aerosol emission in a Rad Tunnel. Atmospheric Environment 31: 451-462. 
ZHU Y., HINDS W.C., SEONGHEON K., SHEN S., SIOUTAS C. 2002: Study of ultrafine particles near a major highway with heavy-duty diesel traffic. Atmospheric Environment 36: 4323-4335.

ZWOZDZIAK A., SAMEK L., SOWKA I., FURMAN L., SKRĘTOWICZ M. 2012: Aerosol Pollution from Small Combustors in a Village. ScientificWorld Journal. 956401.

Streszczenie: Wplyw ruchu drogowego na stęzenia trzech frakcji pylu zawieszonego (PM) i jego główne składniki w dużym mieście Górnego Ślaska. W pracy oceniono wpływ ruchu drogowego na stężenia trzech frakcji pyłu i ich podstawowych składników. Próbki pyłu pobrano równolegle w parze receptorów w Katowicach. Jeden z punktów pomiarowych zlokalizowany w punkcie tzw. tła miejskiego; drugi reprezentował tzw. punkt komunikacyjny. W próbkach oznaczono zawartość węgla organicznego i elementarnego oraz jonów rozpuszczalnych w wodzie. Stwierdzono, że w typowym obszarze miejskim południowej Pol- ski wpływ emisji zanieczyszczeń z silników samochodowych ujawnia się w przypadku pyłu submikronowego i drobnego poprzez wzbogacenie ich cząstek w węgiel elementarny. Wpływ resuspensji pyłu drogowego i glebowego wywołanej ruchem samochodowym na kształtowanie stężeń i składu chemicznego widoczny jest natomiast w przypadku frakcji pyłu grubego.

Stowa kluczowe: $\mathrm{PM}_{1}, \mathrm{PM}_{1-2,5}, \mathrm{PM}_{2,5-10}$, węgiel elementarny, węgiel organiczny, skład chemiczny, rozkład frakcyjny, stanowisko komunikacyjne, tto miejskie

\section{MS. received in December 2013}

\section{Authors' address:}

Instytut Podstaw Inżynierii Środowiska PAN

ul. M. Skłodowskiej-Curie 34

41-819 Zabrze, Poland

e-mail: wioletta.rogula-kozlowska@ipis.zabrze.pl patrycja.rogula-kopiec@ipis.zabrze.pl barbara.mathews@ipis.zabrze.pl krzysztof.klejnowski@ipis.zabrze.pl 